\title{
JACKSON ENERGY SECURITY WORKSHOP: AUGUST 6-7, 2015
}
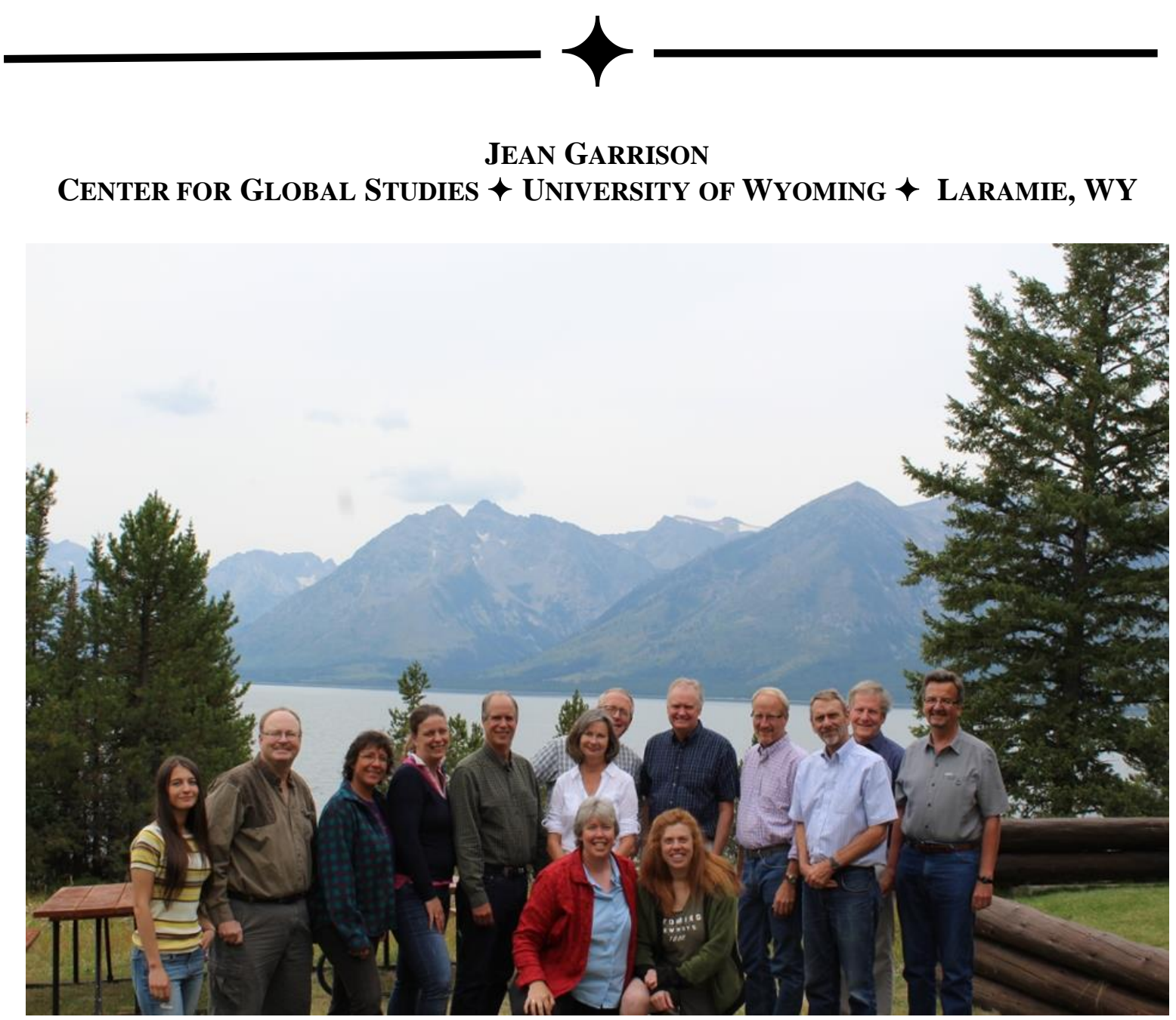

Jackson Energy Security Workshop participants at the UW-NPS Research Station AMK Ranch on August 7, 2015

\section{$\uparrow \quad$ SUMMARY}

The UW Center for Global Studies hosted a twoday workshop focusing on energy security involving interdisciplinary faculty from UW, faculty from the Free University of Berlin, and participants from the non-profit and business sectors. This two day event included presentation of six papers (see agenda below) in three panel sessions addressing a variety of issues including traditional and new approaches to energy security, governance and management issues, and community development and agency. A final roundtable session focused on engaging industry, practitioners, and activists in emerging solutions. The workshop was funded by the School of Energy Resources, the Center for Global Studies, and through a European Union grant through the Colorado European Union Center for Excellence at CU-Boulder. This report proceeds in three parts: 1) rationale and agenda, 2) participant list with bios, 3) a discussion of outcomes to date of the workshop. 


\section{$\downarrow \quad$ RATiOnAle AND AgENDA}

Access to cheap and reliable energy, specifically fossil fuels, has fueled economic growth worldwide, yet natural resources often lie at the heart of conflict and civil strife and can be used as geopolitical tools in foreign policy. Continued reliance on fossil fuels is a reality that also creates an energy future complicated by socio-economic and environmental tradeoffs, issues of sustainability, and the concern over carbon dioxide emissions and climate change. This workshop brought together an interdisciplinary group of scholars, practitioners, and industry and environmental representatives to discuss key issues in the energy security debate, governance and management issues, community development, and environmental values and trade-offs from local to global contexts.

Day 1. Thursday, August $6^{\text {th }}$

Opening \& Session I: Tackling Energy Security Traditional and New Approaches Internationally and in the United States (August 6-9-11:30)

Opening Remarks: Jean Garrison, University of Wyoming

Moderator: Stephanie Anderson, University of Wyoming

Papers:

Jean Garrison, University of Wyoming - "Understanding Evolving Natural Resource Insecurities: Evaluating the Energy-Climate Nexus"

Using a national security perspective combined with a focus on the politics of scarcity in key natural resources as a starting point, this paper examines the politics surrounding how energy and environmental security challenges, from local to global contexts are (and can be) addressed. This research situates environmental security within the classic security debate with a particular focus on the foreign policy challenges inherent in the global climate change debate. The paper presents a decision-making perspective to evaluate how people frame the issue, make decisions, and, thus, can shape what policy choices and decisions are possible.

Chuck Mason, University of Wyoming - "Crude Behavior: How Lifting the Oil Export Ban Reduces Gasoline Prices in the U.S."

Since the 1970s, the U.S. has effectively banned the export of crude oil produced in the US. Because the United States has imported most of the oil it consumed during that period, this ban was largely irrelevant. But this changed with the "fracking" revolution, which quickly opened up vast resources of "tight" oil to exploitation, reduced U.S. oil imports to new lows, and has led to bottlenecked oil supplies in the Midwest and a reduction in crude prices there. The situation has been exacerbated by the inability of most U.S. refineries to efficiently process the light crude coming from these fields. Allowing exports from the U.S. would allow this oil to fetch higher prices, motivating expanding supply over time, while simultaneously motivating US refineries to substitute into heavier crude oil, increasing their efficiency. Over time, these features will induce an increase in both global supply of and global demand for crude, with global crude prices falling slightly. In turn, this will lower gasoline prices globally.

Discussants: Tom Seitz, University of Wyoming; May-Britt Stumbaum, Freie Universität Berlin

Session II: Governance and Management Issues $\underline{\text { (August 6-1:30-3:30) }}$

Moderator: Tom Seitz, University of Wyoming

Papers:

Tanja A. Börzel and Thomas Risse, Freie Universität Berlin - "Environmental Governance is Areas of Limited Statehood"

In the age of globalization, the state is still considered to be the main provider of common goods. While government no longer holds the monopoly on governance, state regulation remains a major instrument to curb negative externalities of private actor activities on the environment. Environmental degradation then tends to be conceptualized as a problem of state failure, where governments do not enact regulation and enforce it. Most states have signed and ratified the major international environmental treaties, and the developing world is catching up with the advanced industrial countries. It seems to be that compliance with, rather than commitment to, environmental regulation has become the main challenge. While industrial countries may lack the willingness to enforce environmental laws, governments in "areas of limited statehood" are often incapable of implementing central decisions including the law. It argues that consolidated statehood forms the exception rather than the rule in the contemporary international system and that "areas of limited statehood" are more widespread than is commonly assumed.

May-Britt Stumbaum, Freie Universität Berlin, and Alfonso Martinez Arranz, Monash University "Cooperation in Nontraditional Security: Energy Security and the Diffusion of Norms and Best Practices in EU-China Relations" 
The paper analyses the diffusion of norms from the EU to China on energy-related issues within the overall framework of European security policy. Energy has a direct impact on all factors of the "comprehensive security" concept that underpins EU security policies, with climate change acting as a threat multiplier. The travelling of norms in energy policy between the EU and China is one of the EU's means to further its security interests: Have norms and best practices been diffusing from the EU towards China? If so, how? The paper focuses on two case studies (transport, electricity generation) with sub-case studies analyzing if and how the EU has been able to promote norms in energy, notably through its environmental policy spilling over to the energy policy field. Bridging academic analysis with policy applicability, this approach aims to provide a basis for formulating future policy recommendations.

Discussants: Roger Coupal, University of Wyoming; Jessica Clement, University of Wyoming

Public Talk - Harlow Summer Series (6:30 p.m.) - Tanja A. Börzel - "On Leaders and Laggards in Environmental Governance and Management: The Case of the European Union"

\section{Day 2: Friday, August 7}

Session III: Community Development and Engagement $\underline{\text { (August 7 - 9:30-11:30) }}$

Moderator: Stephanie Anderson, University of Wyoming

Papers:

Jessica Clement and Steve Smutko, University of Wyoming - "Why Talk? Incentives for the Energy Industry to Engage with Communities in Pursuit of Social License"

This paper investigates the social, economic, and institutional incentives for energy development firms to participate in community engagement and collaboration in order to achieve "social license to operate." Social license in this context refers to society's or a local community's acceptance or approval of a firm's activities or operations. Incentives to collaborate are discussed from the point of view of the firm. We evaluate the effect of various regulatory compliance requirements on the incentive to collaborate, namely the Federal Advisory Committee Act, the National Environmental Policy Act, the Mineral Leasing Act, and the Federal Energy Regulatory Commission's Integrated Licensing Process. We assert that although the attainment of social license is emerging as a key principle in many firms' perception of a sustainable bottom line, institutional barriers to collaboration are a significant disincentive for firms to extend beyond minimum regulatory requirements.
Roger Coupal, University of Wyoming - "Managing and Monitoring the Environmental Impacts of Oil and Gas Development around Communities"

Oil and gas development brings substantial amounts of economic activity, new jobs, and substantial tax revenues for communities. However, the activity can create environmental costs to residents, especially those who do not receive benefits from increased economic activity. This paper explores how, through environmental bonding, reclamation and disturbance caps, communities can better manage environmental costs that can last long after the play ends.

Discussants: David Lawrence, Lawrence Energy Group LLC; Chuck Mason, University of Wyoming

Session IV Roundtable and Closing: Engaging Industry, Practitioners, and Activists in Emerging Solutions (August 7 - 1:00-3:30)

Moderator: Jean Garrison, University of Wyoming

Participants:

David Lawrence, Lawrence Energy Group, LLC Thomas Risse, Freie Universität Berlin Jonathan Schechter, Charture Institute Sam Western, author and correspondent for the Economist and Economist.com

\section{$\downarrow \quad$ WORKSHOP PARTICIPANT BIOS}

Stephanie Anderson is associate director of the Center for Global Studies and associate professor of political science at the University of Wyoming. In 2011-12, she was a senior fellow at the KFG - Transformative Power of Europe at the Freie Universität Berlin researching EU security policy, identity-formation, and crisis management as well as the scholar-in-residence at the EU Centre in Singapore. She is the past recipient of Fulbright Senior Scholar awards to the German Institute for International and Security Affairs (SWP) in Berlin and to the Graduate School of International Studies at Sogang University in Seoul, Korea. Dr. Anderson's research focus is on the European Union (EU) as an international actor, international relations, and security issues. She holds a $\mathrm{PhD}$ from the University of Cambridge, UK.

Tanja Börzel is professor of political science and holds the chair for European Integration at the Freie Universität Berlin. Her research focus and teaching experience lie in the field of institutional theory and governance, European integration, and comparative politics with a focus on Western and Southern Europe. She is coordinator of the Research College "The Transformative Power of Europe" 
as well as the FP7-Collaborative Project "Maximizing the Enlargement Capacity of the European Union.” Börzel also directs the Jean Monnet Center of Excellence "Europe and its Citizens." She holds a PhD from the European University Institute, Florence, Italy.

Jessica Clement is director of the Collaboration Program in Natural Resources at the Haub School of Environment and Natural Resources at the University of Wyoming. She specializes in the study and practice of collaborative governance and collaborative learning related to forests, wildlife, recreation, public lands, and related issues. She has created and facilitated collaborative processes related to natural resource issues for more than 15 years in Colorado, Wyoming, and Montana. Clement has conducted social psychological research regarding the relationship between people and natural resources and taught natural resources policy related subjects for 20 years. She holds a $\mathrm{PhD}$ from Colorado State University.

Roger Coupal is department head and professor in the Department of Agricultural and Applied Economics at the University of Wyoming. His areas of expertise and teaching interests include natural resource policy, community development economic impact analysis, and public lands policy. Coupal's objective is to provide educational opportunities and information for community groups and public officials engaged in policy issues that reside in the nexus of community development and natural resource policy. He holds a $\mathrm{PhD}$ from Washington State University.

Jean Garrison is director of the Center for Global Studies and professor of political science and international studies at the University of Wyoming. Garrison is the past recipient of a Council on Foreign Relations International Affairs Fellowship and has worked in the Office of Chinese and Mongolian Affairs in the U.S. State Department. She also was a visiting fellow with the Maureen and Mike Mansfield Foundation in Washington, DC. Her research interests focus on U.S. foreign policy with an emphasis on U.S.-China relations, leadership, small group dynamics, and energy security. She holds a $\mathrm{PhD}$ from the University of South Carolina.

David Lawrence is an energy executive, investor, and advisor with extensive global experience across the energy industry. In addition, he has worked in academia and government. He is Chairman of Lawrence Energy Group LLC, with interests in emerging stage energy prospects and serves as Chairman of the Yale Climate and Energy Institute Advisory Board. Previously, he served as Executive Vice President of Exploration and Commercial for Shell Upstream Americas and Head of Global Exploration and Executive Vice President Global Exploration in Royal Dutch Shell. He also served the National Ocean Industry Association as Membership Chair, and was a Commissioner on the Aspen Institute Commission on the Arctic. Lawrence received his BA in geology magna cum laude from Lawrence University, and his PhD from Yale in geology and geophysics, receiving the Orville Award for outstanding graduate student research.

Chuck Mason is the H. A. "Dave" True, Jr. Chair in Petroleum and Natural Gas Economics in the Department of Economics and Finance at the University of Wyoming. He is an internationally known scholar who specializes in Environmental and Resource Economics. Mason served as the managing editor of the top international journal in this field, the Journal of Environmental Economics and Management, from 2006-2011. His current research interests include modeling prices for crude oil and natural gas, the role of delivery infrastructure in natural gas markets, and motivations to hold stockpiles of oil and gas. Chuck has a BA and PhD in Economics and a BA in Mathematics, all from the University of California at Berkeley.

Thomas Risse is professor of international relations at the Otto Suhr Institute of Political Science at the Freie Universität Berlin. His previous teaching and research appointments include the Peace Research Institute Frankfurt, the University of Konstanz, the European University Institute, as well as Cornell, Yale, Stanford, and Harvard Universities, and the University of Wyoming. He is coordinator of the Collaborative Research Center "Governance in Areas of Limited Statehood" and codirector of the Research College "Transformative Power of Europe," both funded by the German Research Foundation (DFG). He holds a PhD from the University of Frankfurt.

Thomas Seitz is associate professor in the Global and Area Studies Program at the University of Wyoming. Seitz has received two Fulbright awards to the Philippines and Indonesia and was a visiting professor at Seoul National University in the Republic of Korea. He is the author of Lessons Learned, Lessons Lost: The Evolving Role of Nation Building in U.S. Foreign Policy (University of Manchester Press, 2013). His research focuses on comparative political cultures, nation building, and Southeast Asian politics. He holds a PhD from the University of Cambridge, UK.

Jonathan Schechter is the founder and executive director of the Charture Institute, a Jackson, Wyoming-based think tank. Charture's focus is on "co-thriving," the state in which human populations and the natural world they inhabit both thrive. Geographically, much of Charture's work focuses on places such as Jackson Hole, communities whose character and economy are closely linked to the quality of the surrounding environment. For over 20 years, Schechter has written a bi-weekly column on the region's economy for the Jackson Hole News\&Guide, and he has written and spoken broadly about topics relating to the intersection of the environment and economy. He holds an AB in Human Biology from Stanford University and an MPPM from Yale University. 
Steve Smutko holds the Spicer Chair in Collaborative Practice and is a professor in the Department of Agricultural and Applied Economics and the Haub School of Environment and Natural Resources at the University of Wyoming. The focus of his work is on engaging with local governments, state and federal agencies, and the private and nonprofit sectors to enhance participatory decision-making on complex and often contentious environmental and natural resource policy issues. He teaches graduate and undergraduate courses in negotiation, negotiation analysis, and environmental problem solving. Smutko received a $\mathrm{PhD}$ in economics from Auburn University.

May-Britt U. Stumbaum is head of the NFG Research Group "Asian Perceptions of the EU" at the Freie Universität Berlin, which is funded by the German Ministry of Education and Research. Her previous positions include senior research fellow and executive director of the China and Global Security Program at the Stockholm International Peace Research Institute, among others. Stumbaum has worked as a Visiting Fellow at renowned think tanks in Europe, China and New Zealand and as a "Scholar in Residence" at the Political Section/EU Delegation to China. Her research interests include security policy in the AsiaPacific and US/European security policies towards Asia (particularly India and China), non-traditional security challenges, and transfer, diffusion and the role of perceptions in EU-Asia Pacific security relations. She holds a $\mathrm{PhD}$ from the Freie Universität Berlin.

Samuel Western has served as a correspondent to the Economist and the Economist.com since 1984. Western's work was also published in the Wall Street Journal, LIFE, Sports Illustrated, and High Country News. He is two-time winner of the Wyoming Literary Fellowship (1999) for poetry (2011) for fiction. Previously, Western taught Economic History class at the University of Wyoming (2010-2013), served as Simpson Scholar (2003-2008), taught Ethics at Sheridan College (1999-2005). Western holds a BS degree in Journalism from Oregon State University and an MA in Creative Writing from University of Virginia.

\section{$\downarrow \quad$ OUTCOMES OF THE WORKSHOP}

The workshop represented part of an ongoing interdisciplinary transatlantic partnership between UW and the Free University of Berlin. The workshop organizer, Jean Garrison, is serving as a visiting senior research fellow at the KFG "Transformative Power of Europe" at the Free University of Berlin (Fall 2015). Her paper from the Jackson Energy Security Workshop was the basis for a research paper presentation at the Free University of Berlin on October 26, 2015.

As a follow up, participants in the conference have submitted short briefing papers which will be posted to the CGS website (www.uwyo.edu/globalcenter) in early 2016. It also has shaped a symposia series for Spring 2016 focusing on "Conversation on Regulating Carbon in Coal Country and Beyond - Local, National and International Considerations" - a two part discussion in linked panels in February and April 2016. The purpose of these events is to engage the panel in a frank conversation about the need for international cooperation on carbon, carbon regulation nationally and the reality of needing to prepare for the impacts of carbon regulation in the US generally, and in carbon-focused states like Wyoming more specifically. An interdisciplinary steering committee involving workshop participants is organizing these events. Two participants in the workshop, Dr. Tanja Borzel and Dr. Thomas Risse from the Free University of Berlin serve as senior fellows for the Center for Global Studies and participate in various events on the UW campus. 